\title{
PRODUCTIVITY AND SPIRITUAL HEALING
}

\author{
Pratiwi Ni P. Ayu Lia Nancy, Gorda A.A.N. Oka Suryadinatha \\ Undiknas Graduate School, Bali, Indonesia \\ *E-mail: bee.nancy@hotmail.com
}

\begin{abstract}
Spiritual definitions are very diverse; each individual has a different version of interpreting the spiritual. Among them, there are those who say spiritual is an enlightenment to understand the meaning of life that is answering a philosophical question about how to behave as individuals in dealing with all kinds of problems. Some of the meanings of spirituality are answers to diseases, both physical and non-physical, which are usually caused by stress due to overwork, and ambitions to follow a lifestyle that ultimately becomes a source of productivity barriers. In this study, it is explained how the community interpreted spiritual healing and how the spiritual implementation itself in daily life, social environment, family and work environment. This research uses descriptive qualitative and the findings from this study show that spiritual healing is inherent in the culture of the people in Bali and most of them believe that spiritual healing does exist. Some findings also believe that spiritual is a unity in human life and has actually been done for generations.
\end{abstract}

\section{KEY WORDS}

Spiritual healing, productivity, human resources, stress.

Most individuals want to live in a comfortable world and have facilities such as home, car, socializing and having a good job. Therefore, they work hard to meet those needs and desires. Some people work smartly and a few others work sincerely. To get high productivity, health is a vital and valuable life asset because after all, if health is disrupted, productivity will not be maximal which impacts on work. However, health often does not receive serious attention and is ignored as common, often forgotten. When humans are healthy, they are able to move normally in life, there is rarely a person who is grateful and takes care of this. When mental health and mind begin to fatigue and disturbed, the body will normally give a signal by the onset of disease. Many trends that narrate healthy life are important but they forget that the body cannot be perfectly healthy when the soul is not healthy.

Working with high responsibility, required to work overtime, pressure from superiors and the presence of an unpleasant atmosphere can cause mind, heart and mental disorders. The mind, heart and mental disorders in question such as states of mind that are not calm, stressed out, depressed, accompanied by the emergence of negative emotions, anger, disappointment, revenge, hatred, feelings of guilt, shame, fear, sadness, hurt, which if not dealt with true it will cause physical illness such as diabetes, heart problems, liver disorders, kidney, cancer, bipolar, anxiety, insomnia, etc.

Work that does not fit the heart and a bad environment is not the only cause of disturbance of peace of mind, mind and mental. But also the family environment and social environment should be considered. Because in this modern life, there are so many disturbances of peace of mind, mind and mental caused by lack of human touch in the family environment and social environment. A simple example is the lack of attention and communication from the heart to the hearts of parents towards their children, feelings of lack of confidence causing anxiety and fear to socialize, panic feelings that arise when in a crowded audience and other disorders. Things that seem trivial can actually have a profound impact on one's feelings and thoughts, especially people who are still in their productive age. When a heavy burden is obtained from the work environment, and combined with a less harmonious family atmosphere, it is certainly an appropriate stimulus as a major trigger for both medical and mental disorders. 
The phenomenon of treatment with a spiritual approach that appears in the community seems to be becoming increasingly interested in, especially during this election period. Many legislative candidates who fail to become legislators seek spiritual teacher assistance to be free from the stress, shame, and stress that is largely caused by debt. Regional Integrated Services Unit (UPTD) of the Bali Provincial RSJ in Bangli anticipates services for legislative candidates who are stressed due to failing to step into the legislative seat in the Pileg, April 17, 2019. Bangli RSJ has also prepared 400 beds in anticipation. It is common knowledge that most legislative candidates spend a large enough budget to fund the campaign for the election of legislators. The unpreparedness of legislative candidates facing a failure in the election also has an extraordinary impact on their psyche, especially when their financial resources are depleted and leave a large debt. Besides the emergence of stress and psychiatric disorders in candidates due to several other factors such as fatigue, irregular eating, lack of sleep, excessive anxiety as conveyed by Dr. Basudewa.

Some candidates come to the mental hospital for psychiatric treatment and consultation, but most choose to go to "balian" to overcome their mental problems and pursue spiritual healing with the guidance of spiritual teachers in order that their physical and psychological conditions improve and become productive again. The worst condition occurred in candidates in Buleleng after the legislative election in 2009 where the candidate committed suicide by hanging himself before being given treatment.

This phenomenon shows that the influence of pressure, ambition, shame and failure are so strong, on mental and mental health, making it difficult for the individual to think clearly and even prevent the individual from thinking rationally. Even in severe cases, this can lead to behavior that threatens his safety and the safety of others. Of course, this behavior disrupts self productivity to achieve life goals.

Speaking of spiritual approaches, many people are still mistaken between spiritual healing and religion where the context is very different. Religion is a system of organized. Religion has certain rules that are practiced in daily life which gives satisfaction for those who practice it. But often the thought is indoctrinated from birth and taught. The teachings of these religions in accordance with the religion adopted by parents or the environment. While spiritual is a belief in its relationship with God.

Spiritual intelligence is one of one's abilities to give meaning to life. There are also those who interpret spiritual intelligence as the ability to stay happy and strong in any situation, one of which is to increase productivity, increase peace of mind, mind and mentality even when that calm is reached, all medical complaints experienced by rough bodies will decrease little by little. Spiritual approach can be in the form of prayer guidance, spiritual counselling, and spiritual accompaniment by spiritual leaders or spiritual teachers. Besides that, nowadays there are spiritual places to cleanse themselves in the media such as Pura Tamba Waras, one of them. Not only is the spiritual place being used as a place of "gaining" increasingly appearing in the media, but some types of spiritual medicine are also increasingly in demand such as yoga, meditation and so on to correct disorders that occur in the psychological, mind, and mental like yoga, meditation, and to learn from spiritual teachers according to the beliefs of each individual.

\section{LITERATURE REVIEW}

It has been realized by every individual that health is a basic need in life. In developed countries the behavior of the people is very supportive of healthy living so that it is more proactive to prevent, maintain health while in developing countries the behavior of the people is more towards treatment when attacked by disease alone. Physical health is usually reflected through healthy attitudes and behaviors namely well being paradigm (Priyoto, 2014) where the concept is divided into:

1. Physical health is the first part that distinguishes humans from other species. Humans are not only aware but they know or realize when they feel a difference, such as when someone is sick, lethargic and others that they can feel from the sensory stimulation. From the stimuli of the five senses it can be strengthened or developed 
by the existence of a laboratory examination that can be taken from the network, fluids or the discovery of sub-system activity to establish its health status. People who want to interact with their bodies will always observe body function and will respond to the results of observations to find out their health status.

2. Social health (social health) where this is described by the behavior of other individuals or between one family and another family as an integrated whole system. The destructive social behavior of an individual can be demonstrated by the behavior of driving a vehicle too fast, consuming excessive food, consuming alcohol, smoking and consuming illegal drugs. When the risk begins to be felt and the damaged behavior is still carried out, physical and social phenomena of pain will emerge. Communities that experience rapid change and are influenced by other cultures, find it more difficult to consider social health. The emerging social health disease that arises later is the aging process. Entering the aging process, people are no longer able to do activities outside the routine that are often done before. So the role of the family must continue to encourage having a sense of staying socially useful and feeling physically fit. But when older people live in isolation or isolation they can no longer be unified or cannot be useful in the family system. So that aging is usually associated with a decrease in comprehension, a decrease in body balance and a decrease in body sub-system control. In other words, somatic and physical failure can occur if they are not able to combine their conditions with the way they are still dressed up as young people who are often called "Mislabeling". If they still cannot accept that death as a normal thing will cause an "intolerable ending".

3. Somatic health is a function of the health subsystem at the level of the human system. Discomfort of the body whether there is a change in subsystem or not, must still be perceived as a decrease in the function of the subsystem that can be physically painful. Disease can occur without our awareness, it can be proven by the existence of special tests or broader tests to see various variations in the system's balance to determine the cause of the balance to decrease. Careful genetic research can sometimes be used to predict clear clinical diseases, such as diabetes mellitus. Genetic testing is also useful for determining the health status of the next generation, for example, in the case of sickle-cell careers, so usually the child will suffer the same thing if he marries someone who has a similar condition. Genetic status can be used to assess whether a person is healthy or sick before or sometime after birth.

Spiritual health includes mind, mental and soul. Spiritual health is something that is often ignored According to (Gunawan, 2016), the strength of the mind and mental are very influential on physical condition. For example, a patient with end-stage cancer was sentenced to a life that will not be long by the doctor, but with all the positive things created by the mind and soul that can lead to confidence to recover, it does not reduce the possibility of the patient's chance to recover. The conscious mind can easily be changed from bad patterns to better patterns so that good health and productivity are achieved, while the subconscious mind is more difficult and even requires certain therapies so that the pattern can be changed towards a better direction.

According to Mathis in (Butar, 2015) defines work productivity is a measurement and quantity of work by considering all the costs and things related and needed for the job. Meanwhile, according to Ravianto (Wardani, 2008) work productivity is a continuous result between individual workforce and the environment outside of work, including the physical environment, socio-cultural environment and psychological environment. Whereas according to Nasution (2016) productivity is a concept that describes the relationship between them (the number of goods and services produced) with the source (the amount of labor, capital, land, energy, etc.) used to produce results. Productivity means a comparison between the results achieved (output) with the overall resources used (input). In other words that productivity has two dimensions. The first dimension is effectiveness which leads to the achievement of maximum performance, namely the achievement of targets related to quality, quantity, and time. The second is efficiency related to comparing input with actual use or how the work is carried out (Ashar, 2015). 
Rosito (2010: 37) says that spirituality includes efforts to find, find and maintain something meaningful in their lives. Understanding this meaning will encourage positive emotions both in the process of encouragement which includes the willingness to achieve goals despite facing obstacles, from outside and from within. The impetus included the strength of bravery, persistence, zest. If something meaningful is found then that character will be stronger in a person, especially in the process of maintaining and defending it. The more a person has meaning in his life, the happier and more effective in living his life. Again Maslow said that spiritual experience is the highest peak that can be reached by humans and is an affirmation of its existence as a spiritual being. The highest human experience is the highest human need. Maslow even stated that spiritual experience had passed through the hierarchy of human needs. Motivation in the context of spiritual healing is very important because motivation is a fundamental thing used as a measure of how strong the desire of sufferers to recover. Individual motivation is very important because motivation that is owned will affect one's behavior including spiritual healing activities.

According to Maslow in (Ansory \& Indrasari, 2018), individuals will be motivated to fulfill their needs that are the most prominent or the strongest for them at any given time. Abraham Maslow views humans as a hierarchy of five kinds of needs namely physiological needs, security and protection needs, social needs, self-esteem needs, needs for self-actualization.

The theory from Vroom in (Ansory \& Indrasari, 2018) about cognitive theory of motivation explains why a person will not do something that he believes he cannot do, even if the results of the work he can really want, the level of motivation is determined by three components, namely expectations, instrumentalists and valence. Referring to Vroom's theory, Cut Zurnali (2004) argues that expectation is the strength of the tendency to work properly depending on the strength of the hope that spiritual healing can be used as a way out for illnesses experienced both medically and non-medically.

Spiritual phenomena lately are increasingly in demand by the community because of lifestyle changes. Comfortable life patterns that are formed are no longer just fulfilling basic needs like Maslow's hierarchical theory, but now what is more important is to look luxurious and prestige above all else. Working hard becomes the main choice of the community so that it creates a burden on the mind and causes stress, pressure on the work environment, social and family and not infrequently even many who justify any means to get more income in order to achieve the concept of comfortable living in general. A review of the literature and initial observations were carried out to determine the location of the study and select core informants. Data is collected by observation, documentation and in-depth interviews to get information about how spiritual healing is implemented in life both when carrying out daily activities or applied to careers and business. The data obtained is then verified by source triangulation and triangulation techniques so as to obtain accurate data to be drawn to a conclusion.

\section{METHODS OF RESEARCH}

In this study, the informant used was a spiritual teacher who has spiritual strength and his teachings do not oppose religious norms, 3 people with mental and mental disorders who have been running spiritual healing for more than 1 month. The sampling technique here uses a combination of purposive and accidental sampling. The research location is at Pesraman Giri Taman Sari in the East-Denpasar Penatih area. The data analysis technique used in this study is Miles and Huberman, i.e. the data obtained will be compiled which will then be reduced but in this study there is no reduced data. The data collected is then presented and conclusions drawn. Data verification techniques used are source triangulation and technique triangulation. In source triangulation, 4 informants were used and conducted with interview, observation and documentation techniques. The aim is to ensure that the data obtained from respondents is valid. The data used in this study are primary data that is data obtained directly from the source, and secondary data whose data is obtained through journals, and literature. 


\section{RESULTS AND DISCUSSION}

Perspectives about productive people have surfaced on the surface and being productive is not easy even requires a lot of energy. Many opinions about productive like diligent humans, people who do a lot of positive things and please others, able to work and be creative, able to earn a living for themselves and their families (Jannah, 2011). Lifestyle changes in the 4.0 era, added with a variety of high productivity guidelines made people suffer both physically and non-physically. People who tend to go to night clubs, watch movies and take tranquilizers to relieve stress actually bring them one step closer to depression because actually the drugs and behavior only delay not treat (Wirawan, 2018). From the results of observations on research conducted in the city of Denpasar, shows that although people's lifestyles change and cause many health problems, in the end the community return to spiritual medicine. There are those who come to the spiritual teacher and seek treatment in the traditional way, others follow a healthy lifestyle and are balanced with yoga as a form of spiritual healing. If related to Maslow's motivational theory, human life is basically just to fight and survive. Various methods are used to meet the basic needs of human life. So usually a variety of factors that cause physical and non-physical health disorders occur in the third, fourth and fifth stages (Ansory \& Indrasari, 2018).

This is in line with (Ghani, 2005) that "virtuous bring like", one word with deeds and consistently maintaining a life commitment that is illuminated by the light of spiritual intelligence. That is a form of personal reflection that shepherd his will in the guidelines of nafsul muthmainnah, which are the characteristics of qalbun salim, namely the person who places mahabbah on God as the priority of life. Habits, symbols, rites and traditions of the family environment and business organizations that practice the principles of spiritual intelligence, even business organizations that practice the principles of spiritual intelligence, will guide every person to make spirituality a code of conduct or corporate culture. In organizations that have been able to reach such stages, systems, procedures and management functions will be lighter in weight because each individual will control himself and good corporate governance has a sharpening of dimensions, expanding, internalized, deep, and transcendental because of a sharp dip to the heart we. If synergy is created from individuals and companies that are spiritually based, then the effect becomes very large overall both for the company in general and individuals who work at the company while each individual can practice his devotion and karma together (Hendrawan, 2009).

Spiritual implementation can not only be done on the organization, but can also be done in every day of every action, family environment, and social environment. Referring to the yoga asana movement which by some circles has become a lifestyle, the most important benefit of being able to improve physical health of the body because the movement helps accelerate blood circulation, breathing performed on yoga can provide adequate oxygen intake to the brain and all cells in the organs of the body. It was also stressed that yoga asanas should be balanced with good behavior because yoga is also one of the spiritual paths to be closer to God (Gunarta, 2017). Not only in an organization, in everyday life, but spiritual can also be implemented in someone who is experiencing a family relationship that is less harmonious. The loneliness that arises due to adjustment to the conditions of family relationships is very possible to trigger depression from mild to chronic which often even triggers the desire to commit suicide. This is where the importance of the spiritual relationship between humans and God (Arfandiyah, Hamidah, \& Dewi, 2013).

Referring to the spiritual process carried out by the spiritual teacher in this study is more to the use of prayer, self-cleansing and healing. Especially in the process of self cleaning by painting and using coconut as a means of painting. People's views and the way people talk to each respondent feels more comfortable as a friend of interaction. Medically speaking, coconuts have a myriad of benefits ranging from water containing high potassium and magnesium which, if taken, will help the rehydration process. In addition it prevents dry skin caused by dehydration. Potassium and magnesium contained in intracellular fluid around $98 \%$ can provide additional energy in muscle activity (Susilo, 2015). According to (Gunawan, 2016) in his book entitled The Miracle of Mindbody Medicine, one way to be able 
to dominate positive things in a chaotic mind is to provide motivation or revive an almost faint motivation. The most common way people use in an effort to deal with stresses of mind and stress is by not dealing directly with the source of the problem. People tend to play safe or may not be brave or not strong. Some are still trying to deny, try to forget, suppress or surrender to accept the situation. The most difficult is when a disturbing emotion is unknown at the source, because it has been repressed and hidden in the subconscious mind. In addition to self-cleansing treatment, if in Hinduism, chanting by mentioning the name of God is usually done by chanting the Gayatri da nom name of Shiva, in Islamic religion it is recommended to obey prayer, fasting, and dzikir. Fasting is widely known because it can control the desires and ego (Jauhari, 2011).

Self-cleaning with water is also carried out by Muslims before prayer or worship where there is actually the same meaning as gaining either with a bow or using a spring. According to (Atif \& Khasanah, 2018) ablution provides spiritual and physical benefits which when viewed from the lens of ablution health can clean various types of viruses, bacteria, which are in the teliga, nose and teeth, can facilitate the regeneration of the lender membrane so as to maintain and prevent entry bacteria and viruses are actually very difficult to see in plain sight that endangers the body. According to (Mu'jizah, 2016) the attitude of the people who really care for local wealth has made usada sustainable in Bali until now. This is thought to be able to answer all the turmoil experienced by people in finding their identity. In traditional culture, water is a natural element that is respected and valued because it is the foundation of life and a sacred symbol. Nowadays people are increasingly aggressively visiting the places of fishing which are widely spread on social media where the source of the spring used as a lukewarm is considered to be able to provide inner and inner calmness. there are also those who argue that the washing of springs can provide healing in terms of health

According to (Mu'jizah, 2016) the attitude of the people who really care for local wealth has made usada sustainable in Bali until now. There are treatments for children, adults, pregnant women, people with mental disorders, leprosy and people affected by black magic. This treatment system uses herbs, spices and animals which are carried out with a ceremony or ritual and contain elements of belief. Relating it to the productive paradigm as a whole, it was found that productive is the end result that will be automatically achieved when the elements are fulfilled namely, the individual must be physically healthy, spiritually healthy on a spiritual basis. To better understand it, it is important to instill perception and trust in health behaviors. In his book entitled Theory of Attitudes and Behavior in Health, (Priyoto, 2014) states that individual behavior is influenced by the perception and belief of the individual itself regardless of whether the perception and trust are in accordance with reality.

In the field of physiology, stress is played by the hormone cortisiol. Cortisiol will be secreted by the adrenal glands which were previously through the HPA - Axis (Hypothalamus, Pituitary, Adrenal-Axis) process. Its effect suppresses eosinophil and lymphocytes as cells that are responsible for the body's immunity. Stress results in decreased immune response. Cortisiol hormone starts to increase at 00.00 and the peak at 08.00AM. It was explained that the midnight prayer with a sincere intention because of Allah, had the effect of increasing the immune response. The time of the midnight prayer is onethird of the night, where the hormone cortisol begins to rise. Through dhalat tahajud cortisol hormone levels are controlled by the body in a state of homeostasis. Hormone homeostasis effect cortisol is what gives the effect of increasing the immune response, because our body's immunity is not suppressed (Marzuqi, 2017).

Associated with spiritual healing, whatever means are used to treat if given a holy prayer and a completely sincere feeling, you can imagine how great the benefits for health. Treatment carried out by Dewi Mirah or always recommends patients to shut up to the mother (if the mother is still present) can also be caused by sungkem on the earth or motherland (if the mother is gone) this is a way or form of sincere resignation of a child who begged forgive for the mistakes he has done both intentionally or unintentionally and ask for blessing to be given sincere prayers from a mother in order to obtain a better life later and speed up the healing process. According to (Saputra \& Fitriani, 2019) sungkem has a character value in it where a child should respect parents and be devoted to parents. 


\section{CONCLUSION}

The role of spirituality in life is very deep and broad in its implementation. Based on the findings that researchers gathered from the research site and in accordance with the discussion, that spiritual healing is still in demand by most people both living in urban and rural areas. Living in the modern era actually makes people thirsty for a spiritual touch so that a holy place pops up to do self-cleansing, learn from spiritual masters, adopt a healthy lifestyle by consuming healthy food and not half-heartedly follow the movements of yoga asanas, meditation, recitation and other spiritual ways the positive. The process regarding the stages of spiritual medicine is believed to be one of the ways of treatment that has been passed down from generation to generation by ancestors and is proven by previous research on usada. Although there are still many pros and cons regarding spiritual medicine, which until now still does not find a way to side by side, researchers feel that spiritual healing will continue in the future despite the increasingly sophisticated world of medicine because of local culture and wisdom that is still very attached and thick to the people in Bali . In terms of career and business, it is believed that spiritually can create harmonious and mutually beneficial relationships between individuals and organizations or companies. While in terms of the social and family environment, there will certainly be a good relationship and build positive energy and a cheerful mood that will have an effect on behavior in others. It can be concluded that as human beings it is important to maintain mental and physical health, carry out all activities on a spiritual basis so that emotions and ego do not cross the line and do not cause health problems so productivity is maintained.

From the results of research, the spiritual world cannot be separated from human life. Increasingly studied and researched, spiritual healing should be able to prevent physical ailments from small to chronic risks caused by continuous mental disorder and stress. When the cause of a health problem has been resolved, then even physical interference will be easier to cure. While the role of the medical world should be able to help the public understand how to maintain health from a physical perspective so that there is a balance between physical, spiritual and spiritual. Lack of education which rationalizes the manifestation of spiritual healing on mental and physical health. Some just look at one eye because it is considered a spiritual power is only a suggestion and cannot be proven rationally, especially from the point of view of Hinduism. Spiritual behavior is very difficult to distinguish even separated from culture in each place. Society preserves culture that is contained in spiritual behavior but rarely teaches its meaning and essence to today's young generation so that misunderstandings occur that are continuously inherited by the next generation. With this research, the spiritual teacher is expected to be able to give meaning to life on a spiritual basis to sufferers so that they understand what and what they are doing.

\section{REFERENCES}

1. Anadhi, I. M. G. (2016). Perspektif Air Pada Era Kontemporer. Jurnal Studi Kultural, I(2), 105-109. Retrieved from http://journals.an1mage.net/index.php/ajsk

2. Anandamurti, S. S. (2018). Krisna and Bhagavad Giita. Denpasar: Yayasan Ananda Marga Yoga.

3. Ansory, A. F., \& Indrasari, M. (2018). Manajemen Sumber Daya Manusia. Sidoarjo: Indomedia Pustaka.

4. Arfandiyah, L., Hamidah, K. D., \& Dewi, K. (2013). Hubungan antara Kesepian dengan Ide Bunuh Diri pada Remaja dengan Orangtua yang Bercerai. Jurnal Psikologi Klinis and Kesehatan Mental (Vol. 02).

5. Atif, M., \& Khasanah, U. (2018). Urgensi Wudhu and Relevansinya Bagi Kesehatan Dalam Perspektif Imam Musbikin. Riwayah: Jurnal Studi Hadis, 3 no.2.

6. Bukian, P. A. W. Y., \& Putra, G. N. W. (2018). Pengaruh Terapi Spiritual Gayatri Mantram Terhadap Kemampuan Klien Mengontrol Halusinasi Di Rumah Sakit Jiwa Provinsi Bali Tahun 2018. Jurnal Kesehatan, Vol.3 No.2.

7. Dwi Hartanto, D., \& Endang Nurhayati, dan. (2017). Falsafah Hidup Jnana Marga Yoga 
Dalam Naskah Serat Bhagawad Gita. Jurnal Penelitian Humaniora, Vol. 22 No.1, 1-18.

8. Edison, E., Anwar, Y., \& Komariyah, I. (2017). Manajemen Sumber Daya Manusia. Bandung: Alfabeta.

9. Ghani, M. A. (2005). The Spirituality In Business. Jakarta: Pena Pundi aksara.

10. Gunarta, I. K. (2017). Implementasi Pembelajaran Yoga Dalam Meningkatkan Konsentrasi Belajar. Jurnal Penjaminan Mutu, Vol. 3 No.2. Retrieved from http://ejournal.ihdn.ac.id/index.php/JPM

11. Gunawan, A. W. (2016). The Miracle of Bodymind Medicine. Jakarta: PT. Gramedia Pustaka Utama.

12. Hasyim, W. (2010). Spiritualitas Dalam Perilaku Organisasi. Dinamika Ekonomi and Bisnis, 7(1), 1-12.

13. Hendrawan, S. (2009). Spiritual Management. Bandung: PT. Mizan Pustaka.

14. Humaniora, P., \& Kesehatan and Pemberdayaan Masyarakat Badan Litbang Kesehatan Kementerian Kesehatan, K. (2013). Eksistensi Dukun dalam Era Dokter Spesialis Irfan Ardani (Vol. 1).

15. Indrawati, N. K., Salim, U., Hadiwidjojo, D., \& Syam, N. (2017). Manajemen Risiko Berbasis Spiritual Islam. EKUITAS (Jurnal Ekonomi and Keuangan). https://doi.org/10.24034/j25485024.y2012.v16.i2.2325

16. Jannah, H. (2011). Pemberdayaan Perempuan Dalam Spiritualitas Islam (Suatu Upaya Menjadikan Perempuan Produktif). Pemberdayaan Perempuan Dalam Spiritualitas Islam, Vol. 19 No.

17. Jauhari, I. (2011). Kesehatan dalam Pandangan Islam, (55), 33-57.

18. Khairi, M. S. (2018). Memahami Spiritual Capital dalam Organisasi Bisnis Melalui Perspektif Islam. Jurnal Akuntansi Multiparadigma. https://doi.org/10.18202/jamal.2013.08.7198

19. Kisbiyanto, K. (2016). Kurikulum PGRA Berbasis Kecerdasan Spiritual. ThufuLA: Jurnal Inovasi Pendidikan Guru Raudhatul Athfal, 130. https://doi.org/10.21043/thufula.v4i1.4273

20. Kurniawati, H. (2015). Studi meta analisis spiritual well being and quality of life. Psikologi \& Kemanusiaan, (2011), 978-979.

21. Kartajaya, Hermawan and Indro M, Bembi Dwi. 2009. Ubud, The Spirit of Bali, Jakarta: PT Gramedia Pustaka Utama

22. Kurnianingsih, Ambarwati - Yuniar H, Dodi. 2008. Simulacra Bali Ambiguitas Tradisionalisasi Orang Bali, Yogyakarta: Insist Press

23. Muninjaya, A. A. G. (2010). Manajemen Kesehatan. Jakarta: Buku Kedokteran EGC.

24. Mustaqim, A. H. (n.d.). Membangkitkan Spiritualitas and Memposisikan Puisi Sebagai Obat Jiwa; Kajian Psikologi Spiritual Puisi Shobir POER.

25. Mustika, W. (2015). Dunia Tanpa Suara. Jakarta: PT. Elex Media Komputindo.

26. Marzuqi, I. (2017). Spiritual Enlightment. Jakarta: PT. Elex Media Komputindo.

27. Mu'jizah. (2016). Naskah Usada Sebagai Kearifan Lokal Masyarakat Bali, 191-200. https://doi.org/10.15408/dialektika.v3i2.5189

28. Nasrudin, J. (n.d.). Hanifiya: Jurnal Studi Agama-Agama Relasi Agama, Magi, Sains Dengan Sistem Pengobatan Tradisional-Modern Pada Masyarakat Pedesaan.

29. Novitasari, A., \& Artaria, M. D. (2015). Pengobatan transfer energi sebagai salah satu metode pengobatan tradisional dalam penyembuhan penyakit. Masyarakat, Kebudayaan and Politik, 28(1), 51. https://doi.org/10.20473/mkp.v28i12015.51-63

30. Pratikto, Heri. 2012. Motivasi Spiritual and Budaya Sekolah Berpengaruh Terhadap Kinerja Profesional and Perilaku Konsumsi Guru Ekonomi. Jurnal Pendidikan and Pembelajaran, Vol. 19 No. 1

31. Priyoto. (2014). Teori Sikap and Perilaku Dalam Kesehatan. Nuha Medika.

32. Rahman, M. T., Sulthonie, A. A., \& Solihin, S. (2018). "Sosiologi Informasi Pengobatan Tradisional Religius" Kajian di Masyarakat Perdesaan Jawa Barat. Jurnal Studi Agama and Masyarakat, 14(2), 100. https://doi.org/10.23971/jsam.v14i2.724

33. Razak, A., Kamal Mokhtar, M., Sharazad, W., \& Sulaiman, W. (n.d.). Terapi Spiritual Islami Suatu Model Penanggulangan Gangguan Depresi. 
34. Saputra, R., \& Fitriani, E. (2019). Nilai Karakter Pada Upacara Panggih Temanten Masyarakat Jawa Silaut Desa Tanjung Makmur Kenegaraan Lubuk BuntaS. Jurnal, 2(1). Retrieved from http://perspektif.ppj.unp.ac.id.

35. Sabiq, Z., \& M. As'ad Djalali. (2012). Kecerderdasan Emosi , Kecerdasan Spiritual and Perilaku Prososial. Jurnal Psikologi Indonesia, 1(2), 53-65.

36. Sara, I. T. (n.d.). Kondisi Fisik Tata Ruang Kantor and Produktifitas Pegawai.

37. Shofwa, Y. (2013). Pengaruh Motivasi Spiritual and Kepemimpinan Spiritual Terhadap Kinerja Religius Dosen and Karyawan STAIN Purwokerto. Jurnal Pro Bisnis, 6(1), 1-19.

38. Sugiyono. (2014). Metode Penelitian Kualitatif. Bandung: Alfabeta

39. Susilo, E. A. (2015). Pengaruh Konsumsi Air Kelapa Muda Terhadap Waktu Reaksi Setelah Melakukan Interval Training. Jurnal Kesehatan Olahraga, 94-98.

40. Sutarya, I Gede. 2016. Spiritual Healing, Trend Pariwisata Wellness di Bali. Jurnal Pariwisata Budaya, Volume 1, No. 2

41. Suseno, M. N. (2017). Efektivitas Pembentukan Karakter Spiritual Untuk Meningkatkan Optimisme Terhadap Masa Depan Anak Yatim Piatu. Jurnal Intervensi Psikologi (JIP), 5(1), 1-24. https://doi.org/10.20885/intervensipsikologi.vol5.iss1.art1

42. Setiawan, Irvan. 2018. Pengobatan Tradisional di Desa Lemahabang Kulon, Kec. Lemahabang, Kab. Cirebon. Jurnal Pengbatan Tradisional Patanjala, Vol. 10 No. 1

43. Ushuluddin, F., \& Dan, D. (2016). Self Healing Dalam Mengatasi Post-Power Syndrome ( Studi Kasus di Komplek Ciputat Indah Kota Serang-Banten ).

44. Utami, T. N. (2018). Identifikasi Pencarian Pengobatan Transfer Energi Zikir: Integrasi IImu Kesehatan and Islam. MIQOT: Jurnal IImu-IImu Keislaman, 41(2). https://doi.org/10.30821/miqot.v41i2.482

45. Wardhana, M. (2018). Pendekatan Spiritual Dalam Pelayanan Kesehatan. Denpasar: Vaikuntha International Publication.

46. Wirawan, I. G. B. (2018). Surya Namaskara Benefits for Physical Health. International Journal of Social Sciences and Humanities (IJSSH). https://doi.org/10.29332/ijssh.v2n1.78 